\title{
Pemodelan Pemilihan Lokasi Pembuangan Sampah Akhir pada Dinas Lingkungan Hidup Kota Yogyakarta
}

\author{
Mukh. Nasir Ramdhani ${ }^{1}$ dan Prita Meilanitasari ${ }^{2}$ \\ ${ }^{1}$ Departemen Teknik Industri \\ Universitas Pembangunan Nasional Veteran Yogyakarta \\ Jl. SWK No.104, Ngropoh, Condongcatur, Kec. Depok, Kab. Sleman, Yogyakarta 55283 \\ ${ }^{2}$ Graduate School of Management of Technology \\ Hanyang University \\ 222, Wangsimni-ro, Seongdong-gu, Seoul 04763, Korea \\ email :mn.ramdhani@upnyk.ac.id ; dintamio@hanyang.ac.kr \\ doi: https://doi.org/10.31315/opsi.v12i2.3144
}

Received: $21^{\text {st }}$ September 2019; Revised: $22^{\text {nd }}$ October 2019; Accepted: $27^{\text {th }}$ November 2019; Available online: $1^{\text {st }}$ December 2019; Published regularly: December 2019

\begin{abstract}
Population growth rate and urban lifestyle have an impact on increasing the volume of waste. The problem is related to the concept of Municipal Waste Collection (MWC) for waste management. Waste management considers transportation and distribution from the Temporary Disposal Site (TPS) to the location of the Final Disposal Site (TPA). Routing and allocation for waste disposal in the urban area gave a big concern for the society. This study will raise the issue of allocation, distribution and transportation to support overall waste management in urban areas. This study will use Integer Linear Programming approach for modeling the selection of the final location of TPA by considering the distance from each TPS to the TPA. This study also considers the conversion value of the weight of municipal solid waste in Yogyakarta City. In the practice, Yogyakarta City has 1 TPA with 73 TPS. Authors generate 1 new TPA as an alternative. This study will give an alternative allocation, distribution and transportation from each TPS which optimized the capacity of TPA.
\end{abstract}

Keywords: Municipal Waste Collection; Landfills location; Distribution; Waste Management; Integer Linier Programming

\begin{abstract}
ABSTRAK
Laju pertumbuhan suatu penduduk serta ekonomi masyarakat perkotaan akan berdampak pada peningkatan volume sampah yang dihasilkan. Permasalahan tersebut berkaitan dengan konsep Municipal Waste Collection (MWC). Pengelolaan sampah dapat mempertimbangkan faktor transportasi dan distribusi dari Tempat Pembuangan Sementara (TPS) ke lokasi Tempat Pembuangan Akhir (TPA). Dengan pendekatan Integer Linier Programming penelitian ini melakukan pemodelan pemilihan lokasi akhir sampah dengan mempertimbangkan jarak dari masing-masing TPS menuju ke TPA di Kota Yogyakarta. Penelitian ini juga mempertimbangkan nilai konversi dari berat sampah kota yang dihasilkan menjadi volume sampah yang di angkut menuju TPA. Kota Yogyakarta hanya mempunyai 1 TPA dengan 73 TPS. Penambahan 1 lokasi TPA baru sebagai alternatif pemilihan lokasi pembuangan sampah dilakukan dalam penelitian ini. Hasil penelitian ini menunjukkan bahwa beberapa alternatif alokasi pembuangan sampah dengan mempertimbangkan distribusi dan transportasi pada masing-masing TPS yang dapat mengoptiomalkan kapasitas TPA.
\end{abstract}

Kata Kunci: Municipal Waste Collection; Lokasi Pembuangan Sampah Akhir; Distribusi; Manajemen Sampah; Integer Linier Programming

\section{PENDAHULUAN}

Semakin pesatnya pertumbuhan penduduk di kota besar maka masalah kependudukan pun semakin kompleks. Salah satu masalah yang kini dihadapi pemerintah kota adalah masalah penanganan sampah. Penanganan sampah merupakan layanan wajib dan penting yang harus disediakan oleh pemerintah di berbagai negara untuk menjaga kebersihan perkotaan (Huang \& Lin, 2015). Pertumbuhan ekonomi menunjukkan sejauh mana aktivitas perekonomian akan menghasilkan tambahan pendapatan masyarakat pada suatu periode tertentu (Sukirno, 2006). Pertumbuhan ekonomi mengarah pada perkembangan kegiatan 
perekonomian yang menyebabkan

bertambahnya barang dan jasa yang diproduksi dan kemakmuran masyarakat meningkat (Sukirno, 1994). Peningkatan penduduk suatu daerah, migrasi penduduk, dan perkembangan industri di suatu daerah dapat meningkatkan produksi sampah (Mulasari et al., 2016). Dengan bertambahnya pendapatan akan memicu tingkat konsumsi barang dan jasa, yang kemudian hasil akhir dari kegiatan konsumsi barang dan jasa adalah berupa sampah perkotaan. Permasalahan tersebut berkaitan dengan konsep Municipal Waste Collection (MWC) dimana MWC merupakan aktivitas multidisiplin yang mencakup pemisahan sumber sampah, penyimpanan, pengumpulan sampah, transfer dan transportasi, pengolahan dan pemulihan, dan pembuangan akhir sampah (Das \& Bhattacharyya, 2015). Tujuannya adalah untuk memperhitungkan pengeluaran dalam pengelolaan sampah kota (Jacobsen, Buysse, \& Gellynck, 2013). Perencanaan dalam membuat kebijakan sangat penting untuk menemukan cara yang efisien dan berkelanjutan untuk pengumpulan dan pembuangan sejumlah sampah kota (Xue, Coa, \& Li, 2015). Pengelolaan sampah yang tidak mempertimbangkan faktor transportasi dan distribusi pada lokasi pembuangan akhir yang tepat akan berakibat terlantarnya sampah sehingga dapat menimbulkan dampak negatif terhadap kesehatan juga akan sangat mengganggu kelestarian fungsi lingkungan dan estetika.

Sistem distribusi dan transportasi sampah kota dapat berkaitan dengan rute yang harus ditempuh oleh kendaraan pengangkut sampah dari beberapa Tempat Pembuangan Sememtara (TPS) menuju ke Tempat Pembuangan Akhir (TPA). Beberapa penelitian pada permasalahan pengumpulan sampah kota telah dilakukan, seperti penelitian dari (Usman et al., 2013) melakukan pengembangan model pemilihan lokasi akhir sampah perkotaan yang ada di Jakarta timur. Penelitian ini bertujuan untuk mengembangkan model pemilihan lokasi pembuangan sampah perkotaan terbaik. Dengan mempertimbangkan jarak pada amsing-masing TPS ke TPA. Penelitian dari (Ramdhani et al., 2018) mengembangkan model optimasi pada jadwal keberangkatan kendaraan serta penugasan kendaraan yang melayani pengangkutan di TPS pada masing-masing rute dengan mempertimbangkan route sequencing pada setiap kendaraan yang homogen. Pada
(Islam et al., 2015) mempertimbangkan satu pusat distribusi yang melayani beberapa permintaan konsumen pada setiap rangkaian titik penjualan dengan menggunakan kendaraan dengan batasan kapasitas muatan. (Buhrkal et al., 2012) melakukan penelitian dengan bagaimana cara untuk mengumpulkan sampah dengan cara yang efisien pada Danish Garbage Collection Company Dengan pendekatan model waste collection vehicle routing problem with time windows. Dengan mempertimbangkan jarak minimum antara titik penjualan dan pusat distribusi. Penelitian ini menggunakan pendekatan heuristic untuk mendapatkan minimal total jarak perjalanan. Sedangkan pada penelitian ini, dengan menggunakan pemodelan pemilihan lokasi akhir sampah dengan mempertimbangkan jarak dari masing-masing TPS menuju ke TPA. Penelitian ini dibangun dengan pendekatan Integer Linier Programming untuk menghasilkan alokasi distribusi dari masing-masing TPS ke beberapa TPA dengan meminimalisasi jarak tempuh optimal dari TPS ke TPA.

Dari beberapa tinjauan penelitianpenelitian sebelumnya, mayoritas penelitian dilakukan untuk menentukan jalur transportasi sampah yang akan dilalui oleh truk-truk pengumpul dan pengangkut sampah sementara penelitian ini difokuskan pada penentuan lokasi TPA. Penelitian ini dilandasi pemikiran bahwa jumlah TPS yang tersebar di wilayah perkotaan sangat banyak sementara jumlah TPA terbatas. Pemerintah Kota Yogyakarta melalui Dinas Lingkungan Hidup (DLH) sebagai pengelola dalam permasalahan sampah kota, membutuhkan sebuah sistem dalam pengelolaan distribusi sampah. DLH mempunyai TPS sejumlah 73 titik lokasi dan 1 TPA Piyungan. Dari permasalahan di atas maka diperlukan model pengelolaan distribusi sampah kota, maka dilakukan pengembangan model pemilihan lokasi akhir sampah perkotaan. Penelitian ini difokuskan pada kondisi saat ini, sehingga pemilihan lokasi terbaik akan dibatasi oleh pemilihan jarak terdekat dari tempat pengumpulan sampah sementara (TPS) ke tempat penampungan akhir (TPA), volume sampah yang dihasilkan oleh masyarakat per hari, dan kapasitas maksimum sampah yang dapat ditampung oleh TPA per hari. Dan penulis mengasumsikan ada tambahan 1 TPA Sidorejo sebagai usulan alternatif solusi penanganan sampah di Kota Yogyakarta. Diharapkan dengan pemilihan lokasi pembuangan sampah dari 73 
TPS ke 2 TPA ini dapat membantu pemerintah setempat dalam mengelola sampah perkotaan saat ini.

\section{METODE PENELITIAN}

\subsection{Pengumpulan Data}

Sebagai langkah awal penelitian ini dengan melakukan pengumpulan data dari pihak-pihak terkait di Dinas Lingkungan Hidup Pemerintah Kota Yogyakarta. Adapun data yang digunakan pada masing-masing TPS dan TPA, dan jarak titik asal dari TPS ke titik tujuan TPA.

Dalam pemilihan lokasi TPA yang optimal untuk masing-masing TPS di DIY dengan menggunakan metode integer linier programming (0-1) yang bertujuan untuk menentukan TPA yang mana yang optimal (berdasarkan jarak tempuh) dan dijadikan lokasi pembuangan sampah pada tiap-tiap lokasi TPS. Data yang digunakan adalah data yang berasal

\section{Destinasi Asal (Allarak dari Ai ke Bj (Yij) Destinasi Tujuan (Bj) Jarak dari Ai ke Bj (Yij) Destinasi Asal (Ai)}

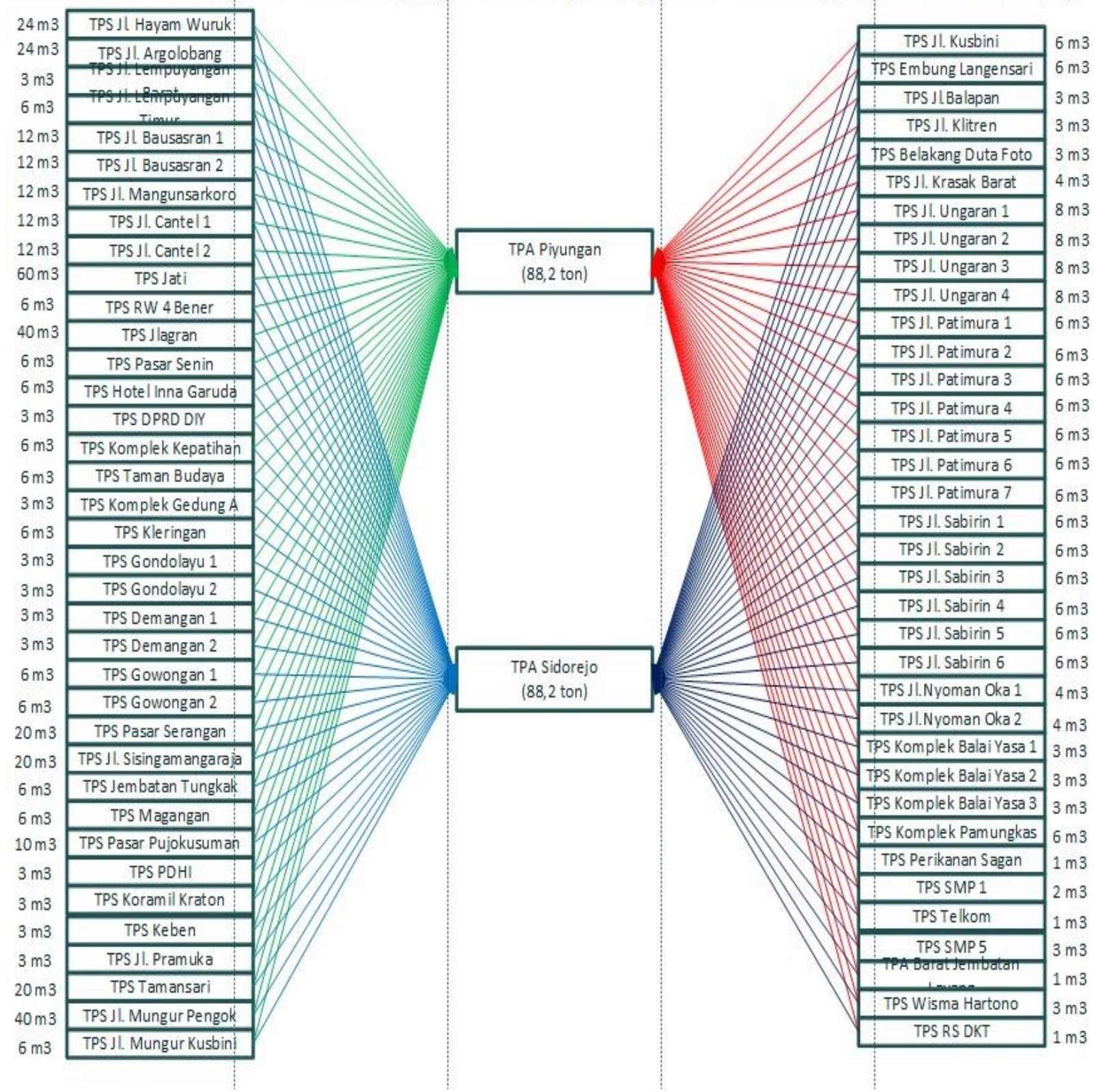

Gambar 1. Network Flow untuk Pemodelan Formulasi

dalam penelitian ini adalah lokasi Tempat Pembuangan Sementara (TPS), lokasi Tempat Pembungan Akhir (TPA), Kapasitas maksimum dari 73 TPS Permanen yang dilayani Dinas Lingkungan Hidup Kota Yogyakarta, serta 2 TPA yaitu TPA Piyungan dan TPA Sidorejo 
sebagai usulan alternatif. Peta lokasi kedua TPA dapat dilihat pada Gambar 2.

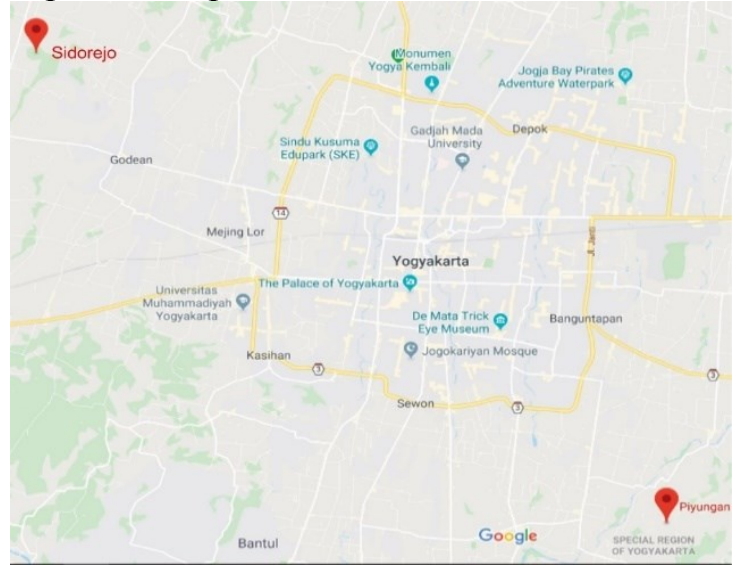

Gambar 2. Lokasi TPA Sidorejo dan TPA Piyungan

Penelitian ini hanya berfokus untuk pemodelan pemilihan lokasi pada masingmasing TPS menuju ke TPA dengan mempertimbangkan waktu tempuh kendaraan yang didapat dari Google Maps. Dengan asumsi bahwa jarak tempuh di ambil dengan menggunakan Google Maps pada setiap TPS yang dikelola oleh Dinas Lingkungan Hidup Kota Yogyakarta. Network flow untuk pemodelan formulasi dapat dilihat pada Gambar 1.

Pada Gambar 1, formulasi pada penelitian ini didasarkan pada jarak yang ditempuh dari $A_{i}$ destinasi awal (TPS Permanen) menuju ke $B_{j}$ destinasi akhir (TPA) serta volume sampah yang diangkut pada tiap TPS. Dimana $Y_{i j}$ adalah jarak yang ditempuh kendaraan dari destinasi $A$ ke- $i$ menuju destinasi $B$ ke- $j$.

Data pada Tabel 1 adalah data jarak antara masing-masing TPS ke TPA yang digunakan dan volume sampah pada tiap TPS. Berdasarkan data daya timbangan TPA Piyungan pada tahun 2016, rata - rata volume sampah Kota Yogyakarta per hari adalah 176,4 ton. Sebagai informasi, daya tampung maksimal untuk masing-masing TPA disamakan dengan ratarata volume sampah per perhari yakni 88,2 ton untuk TPA Piyungan, dan 88,2 ton untuk TPA Sidorejo.

Total volume sampah untuk semua TPS adalah $593 \mathrm{~m}^{3}$. Volume sampah tersebut harus dapat ditampung pada masing-masing TPA. Untuk menentukan nilai berapa toh volume sampah Kota Yogyakarta, maka digunakan nilai 0,19 sebagai koefisian nilai rata-rata faktor konversi mixed municipal waste berdasarkan dari penelitian (Sarajevo, 2015). Formulasi konversi dari satuan volume $\left(\mathrm{m}^{3}\right)$ ke satuan berat (ton) berdasarkan pada (Sarajevo, 2015) adalah: Volume $\left(\mathrm{m}^{3}\right) \times$ Conversion Factor $=$ Weight in tons

Berdasarkan persamaan (1), maka jumlah tonase sampah yang dihasilkan oleh Kota Yogyakarta per hari adalah 112,7 tons.

\subsection{Formulasi Model Matematis}

Formulasi yang digunakan dalam penelitian ini dapat didefinisikan sebagai ( $i$ ) untuk lokasi pada setiap TPS dan $(j)$ untuk lokasi tujuan pembuangan sampah TPA. Parameter dan variabel keputusan yang digunakan penelitian ini adalah $Y_{i j}$ merupakan jarak dari TPS (i) menuju ke TPA $(j), V_{j i}$ merupakan volume timbunan sampah pada TPA $(j)$ dari TPS $(i)$ per tonase (ton), $d_{i}$ adalah demand sampah pada TPS (i) per kubik (m3), $C_{j}$ merupakan kapasitas maksimum TPA $(j)$ per tonase (ton), $C F_{j}$ merupakan faktor konversi sampah kota (mixed municipal waste) pada TPA (j). Sedangkan variabel keputusan pada penlitian ini adalah jarak optimal pembuangan sampah dari TPS ke TPA $(Z)$, dan pemilihan lokasi terbaik $\left(X_{i j}\right)$.

Pemodelan pemilihan lokasi dalam formulasi matematis yang digunakan adalah sebagai berikut:

$\operatorname{Min} Z=\sum_{i=1}^{n} \sum_{j=1}^{m} Y_{i j} X_{i j}$

Subject To:

$$
\begin{array}{ll}
\sum_{i=1}^{n} V_{j i} X_{i j} \leq C_{j} & , \forall j \in J \\
\sum_{j=1}^{m} X_{i j} & , \forall i \in I \\
V_{j i}=C F_{j} \times d_{i} & , \forall j \in J, \forall i \in I \\
X_{i j}=\text { integer } &
\end{array}
$$

Fungsi tujuan pada persamaan (2) untuk meminimasi jarak tempuh pembuangan dari TPS menuju TPA. Batasan (3) untuk memastikan sampah yang masuk pada TPA dari TPS tidak melebihi kapasitas maksimum. Batasan (4) adalah variabel keputusan dalam untuk menentukan pemilihan lokasi terbaik. Batasan (5) menentukan volume sampah yang masuk pada TPA dari TPS sesuai dengan satuan kapasitas. Batasan (6) merupakan variabel integer. 


\section{HASIL DAN PEMBAHASAN}

Pada kondisi saat ini, Dinas Lingkungan Hidup Pemerintah Kota Yogyakarta hanya memiliki satu TPA (TPA Piyungan) untuk melayani proses pembuangan sampah akhir pada seluruh TPS yang tersebar di Kota Yogyakarta. Pada penelitian ini mengenerate satu lokasi baru sebagai usulan TPA baru untuk melayani seluruh TPS. Dari masing-masing lokasi TPS munuju TPA menjadi input dalam penglolahan data.
Data yang diperoleh kemudian masukkan ke dalam perhitungan matematis dengan bantuan software linier programming. Hasil dari running formulasi matematika serta data dapat diselesaikan dengan mendapatkan global optimum solution.

Berdasarkan data pada Gambar 1 dan Tabel 1, menunjukkan total sampah pada masingmasing TPS dan kapasitas masing-masing TPA dengan jarak antar TPS dan TPA minimum sebesar $1069.583 \mathrm{~km}$. Dari hasil perhitungan

Tabel 1. Matriks Jarak TPS- TPA dan Volume Sampah di tiap TPS

\begin{tabular}{|c|c|c|c|c|c|}
\hline \multirow{2}{*}{ Lokasi TPS } & \multicolumn{2}{|c|}{ Jarak ke TPA $(\mathrm{Km})$} & \multirow{2}{*}{ Lokasi TPS } & \multicolumn{2}{|c|}{ Jarak ke TPA (Km) } \\
\hline & TPA Piyungan & TPA Sidorejo & & TPA Piyungan & TPA Sidorejo \\
\hline TPS Jl. Hayam Wuruk & 13.3 & 18.4 & $\begin{array}{l}\text { TPS Koramil } \\
\text { Kraton }\end{array}$ & 14.1 & 18.8 \\
\hline TPS J1. Argolobang & 14.1 & 22.8 & TPS Keben & 12.1 & 19.9 \\
\hline $\begin{array}{l}\text { TPS J1. Lempuyangan } \\
\text { Barat }\end{array}$ & 13.7 & 22.5 & TPS Jl. Pramuka & 8.8 & 22.4 \\
\hline $\begin{array}{l}\text { TPS Jl. Lempuyangan } \\
\text { Timur }\end{array}$ & 13.9 & 22.8 & TPS Tamansari & 14.3 & 19.1 \\
\hline TPS J1. Bausasran $1 \& 2$ & 12.6 & 23.1 & $\begin{array}{l}\text { TPS Jl. Mungur } \\
\text { Pengok }\end{array}$ & 13.7 & 19.8 \\
\hline TPS J1. Mangunsarkoro & 12.7 & 20.4 & $\begin{array}{l}\text { TPS Jl. Mungur } \\
\text { Kusbini }\end{array}$ & 15.1 & 19.5 \\
\hline TPS J1. Cantel $1 \& 2$ & 12.9 & 24.1 & TPS Jl. Kusbini & 14 & 18.9 \\
\hline TPS Jati & 18.9 & 24.7 & $\begin{array}{l}\text { TPS Embung } \\
\text { Langensari }\end{array}$ & 14 & 19 \\
\hline TPS RW 4 Bener & 18.5 & 14.8 & TPS Jl.Balapan & 14.8 & 19.9 \\
\hline TPS Jlagran & 15.2 & 16.4 & TPS Jl. Klitren & 15 & 19.4 \\
\hline TPS Pasar Senin & 14.6 & 18.5 & $\begin{array}{l}\text { TPS Belakang Duta } \\
\text { Foto }\end{array}$ & 15 & 19.5 \\
\hline TPS Hotel Inna Garuda & 15 & 17.7 & $\begin{array}{l}\text { TPS J1. Krasak } \\
\text { Barat }\end{array}$ & 14.3 & 18.7 \\
\hline TPS DPRD DIY & 15.1 & 17.8 & $\begin{array}{l}\text { TPS Jl. Ungaran 1, } \\
2,3 \& 4\end{array}$ & 14.3 & 17.7 \\
\hline TPS Komplek Kepatihan & 13.9 & 18.1 & $\begin{array}{l}\text { TPS Jl. Patimura } \\
1, \ldots, 7\end{array}$ & 14.5 & 17.9 \\
\hline TPS Taman Budaya & 13 & 18.7 & $\begin{array}{l}\text { TPS Jl. Sabirin } \\
1, \ldots, 6\end{array}$ & 16.2 & 17.3 \\
\hline $\begin{array}{l}\text { TPS Komplek Gedung } \\
\text { Agung }\end{array}$ & 13.9 & 19 & $\begin{array}{l}\text { TPS Jl.Nyoman } \\
\text { Oka } 1 \& 2\end{array}$ & 14.9 & 17.7 \\
\hline TPS Kleringan & 17.7 & 17 & $\begin{array}{l}\text { TPS Komplek Balai } \\
\text { Yasa 1,2, \&3 }\end{array}$ & 15.4 & 19.1 \\
\hline TPS Gondolayu $1 \& 2$ & 16.8 & 16.5 & $\begin{array}{l}\text { TPS Komplek } \\
\text { Pamungkas }\end{array}$ & 14.4 & 18.1 \\
\hline TPS Demangan $1 \& 2$ & 14.7 & 19.6 & $\begin{array}{l}\text { TPS Perikanan } \\
\text { Sagan }\end{array}$ & 15.8 & 17.8 \\
\hline TPS Gowongan $1 \& 2$ & 17.7 & 17 & TPS SMP 1 & 16.5 & 17.6 \\
\hline TPS Pasar Serangan & 14.9 & 17.2 & TPS Telkom & 16.3 & 17.4 \\
\hline $\begin{array}{l}\text { TPS Jl. } \\
\text { Sisingamangaraja }\end{array}$ & 10.7 & 21.2 & TPS SMP 5 & 14.3 & 18 \\
\hline TPS Jembatan Tungkak & 10.9 & 21.6 & $\begin{array}{l}\text { TPA Barat } \\
\text { Jembatan Layang }\end{array}$ & 13.9 & 19.1 \\
\hline TPS Magangan & 13.4 & 19 & $\begin{array}{l}\text { TPS Wisma } \\
\text { Hartono }\end{array}$ & 16.1 & 16.8 \\
\hline TPS Pasar Pujokusuman & 11.8 & 20.3 & TPS RS DKT & 16.4 & 17.6 \\
\hline TPS PDHI & 13.7 & 18.8 & & & \\
\hline
\end{tabular}


Tabel 2. Hasil Pemilihan Alokasi TPS pada TPA

\begin{tabular}{|c|c|}
\hline Lokasi TPS & $\begin{array}{c}\text { Lokasi } \\
\text { Pembuangan } \\
\text { Sampah Terbaik }\end{array}$ \\
\hline TPS Jl. Hayam Wuruk & TPA Piyungan \\
\hline TPS Jl. Argolobang & TPA Piyungan \\
\hline TPS Jl. Lempuyangan Barat & TPA Piyungan \\
\hline $\begin{array}{l}\text { TPS Jl. Lempuyangan } \\
\text { Timur }\end{array}$ & TPA Piyungan \\
\hline TPS Jl. Bausasran $1 \& 2$ & TPA Piyungan \\
\hline TPS Jl. Mangunsarkoro & TPA Piyungan \\
\hline TPS J1. Cantel $1 \& 2$ & TPA Piyungan \\
\hline TPS Jati & TPA Sidorejo \\
\hline TPS RW 4 Bener & TPA Sidorejo \\
\hline TPS Jlagran & TPA Sidorejo \\
\hline TPS Pasar Senin & TPA Piyungan \\
\hline TPS Hotel Inna Garuda & TPA Piyungan \\
\hline TPS DPRD DIY & TPA Piyungan \\
\hline TPS Komplek Kepatihan & TPA Piyungan \\
\hline TPS Taman Budaya & TPA Piyungan \\
\hline $\begin{array}{l}\text { TPS Komplek Gedung } \\
\text { Agung }\end{array}$ & TPA Piyungan \\
\hline TPS Kleringan & TPA Sidorejo \\
\hline TPS Gondolayu $1 \& 2$ & TPA Sidorejo \\
\hline TPS Demangan $1 \& 2$ & TPA Piyungan \\
\hline TPS Gowongan $1 \& 2$ & TPA Sidorejo \\
\hline TPS Pasar Serangan & TPA Piyungan \\
\hline TPS JI. Sisingamangaraja & TPA Piyungan \\
\hline TPS Jembatan Tungkak & TPA Piyungan \\
\hline TPS Magangan & TPA Piyungan \\
\hline TPS Pasar Pujokusuman & TPA Piyungan \\
\hline TPS PDHI & TPA Piyungan \\
\hline
\end{tabular}

pada pemodelan pemilihan lokasi pembuangan sampah, didapatkan hasil pada Tabel 2.

Berdasarkan pada hasil yang disajikan pada Tabel 2, didapatkan 65 TPS yang dialokasikan ke TPA Piyungan dengan total 87,97 ton sampah, sedangkan 8 TPS dialokasikan pada TPA Sidorejo dengan total 24,7 ton sampah. Dengan jumlah total sampah Kota Yogyakarta mencapai 112,67 ton, dimana sampah tersebut harus di buang ke TPA pada setiap TPS yang ada.

Pada perkembangannya dengan jarak pada masing-masing TPS ke TPA adalah tetap yakni $1069.583 \mathrm{~km}$, dan adanya permintaan pengangkutan sampah pada masing-masing TPS meningkat hingga $55 \%$. Maka alokasi pemilihan tempat pembungan sampah pada setiap TPS akan berubah. Peningkatan tersebut

\begin{tabular}{ll}
\hline Lokasi TPS & $\begin{array}{c}\text { Lokasi Pembuangan } \\
\text { Sampah Terbaik }\end{array}$ \\
\hline TPS Koramil Kraton & TPA Piyungan \\
TPS Keben & TPA Piyungan \\
TPS Jl. Pramuka & TPA Piyungan \\
TPS Tamansari & TPA Piyungan \\
TPS Jl. Mungur Pengok & TPA Piyungan \\
TPS Jl. Mungur Kusbini & TPA Piyungan \\
TPS Jl. Kusbini & TPA Piyungan \\
TPS Embung Langensari & TPA Piyungan \\
TPS Jl.Balapan & TPA Piyungan \\
TPS Jl. Klitren & TPA Piyungan \\
TPS Belakang Duta Foto & TPA Piyungan \\
TPS Jl. Krasak Barat & TPA Piyungan \\
TPS Jl. Ungaran 1, 2, $3 \& 4$ & TPA Piyungan \\
TPS Jl. Patimura 1,..,7 & TPA Piyungan \\
TPS Jl. Sabirin 1,...6 & TPA Piyungan \\
TPS Jl.Nyoman Oka 1 \& 2 & TPA Piyungan \\
TPS Komplek Balai Yasa 1,2, & TPA Piyungan \\
TPS Komplek Pamungkas & TPA Piyungan \\
TPS Perikanan Sagan & TPA Piyungan \\
TPS SMP 1 & TPA Piyungan \\
TPS Telkom & TPA Piyungan \\
TPS SMP 5 & TPA Piyungan \\
TPA Barat Jembatan Layang & TPA Piyungan \\
TPS Wisma Hartono & TPA Piyungan \\
TPS RS DKT & TPA Piyungan \\
\hline
\end{tabular}

ditujukan untuk memaksimalkan daya tapung TPA. Pada Tabel 4.2 Dengan total tumpukan sampah pada semua TPS menjadi $919,15 \mathrm{~m}^{3}$ atau setara dengan 174,64 ton sampah, maka dapat dilihat hasil alokasi pemilihan pembuangan sampah pada masing-masing TPS pada Tabel 3 . Hasil yang didapatkan pada Tabel 3 menujukkan bahwa 53 TPS yang dialokasikan pada TPA Piyungan dengan total sampah yang masuk sebesar 87.172 ton sampah. Dan 20 TPS dialokasikan pada TPA Sidorejo dengan total yang masuk sebesar 87.47 ton sampah. Total sampah Kota Yogyakarta dengan peningkatan sampah sebesar 55\% adalah 174,64 ton sampah yang harus di buang pada TPA Piyungan dan Sidorejo. 
Tabel 3. Hasil Pemilihan Alokasi TPS pada TPA dengan peningkatan sampah 55\%

\begin{tabular}{|c|c|}
\hline Lokasi TPS & $\begin{array}{l}\text { Lokasi Pembuangan } \\
\text { Sampah Terbaik }\end{array}$ \\
\hline TPS J1. Hayam Wuruk & TPA Sidorejo \\
\hline TPS Jl. Argolobang & TPA Sidorejo \\
\hline TPS J1. Lempuyangan Barat & TPA Piyungan \\
\hline $\begin{array}{l}\text { TPS J1. Lempuyangan } \\
\text { Timur }\end{array}$ & TPA Piyungan \\
\hline TPS Jl. Bausasran $1 \& 2$ & TPA Piyungan \\
\hline TPS Jl. Mangunsarkoro & TPA Piyungan \\
\hline TPS Jl. Cantel $1 \& 2$ & TPA Piyungan \\
\hline TPS Jati & TPA Sidorejo \\
\hline TPS RW 4 Bener & TPA Sidorejo \\
\hline TPS Jlagran & TPA Sidorejo \\
\hline TPS Pasar Senin & TPA Piyungan \\
\hline TPS Hotel Inna Garuda & TPA Piyungan \\
\hline TPS DPRD DIY & TPA Piyungan \\
\hline TPS Komplek Kepatihan & TPA Piyungan \\
\hline TPS Taman Budaya & TPA Piyungan \\
\hline $\begin{array}{l}\text { TPS Komplek Gedung } \\
\text { Agung }\end{array}$ & TPA Piyungan \\
\hline TPS Kleringan & TPA Sidorejo \\
\hline TPS Gondolayu $1 \& 2$ & TPA Sidorejo \\
\hline TPS Demangan $1 \& 2$ & TPA Piyungan \\
\hline TPS Gowongan $1 \& 2$ & TPA Sidorejo \\
\hline TPS Pasar Serangan & TPA Sidorejo \\
\hline TPS Jl. Sisingamangaraja & TPA Piyungan \\
\hline TPS Jembatan Tungkak & TPA Piyungan \\
\hline TPS Magangan & TPA Piyungan \\
\hline TPS Pasar Pujokusuman & TPA Piyungan \\
\hline TPS PDHI & TPA Piyungan \\
\hline
\end{tabular}

Dari pemodelan pemilihan lokasi pembuangan sampah akhir, dilakukan analisis sensitivitas dengan merubah parameter demand sampah pada TPS $\left(d_{i}\right)$. Perubahan tersebut ditujukan untuk pengalokasian lokasi dengan adanya kenaikkan demand dari kondisi existing hingga pada kapasitas maksimul daya tamping sampah pada lokasi pembuangan akhir sampah. Hasil alokasi TPS ke TPA berdasarkan berubahan kenaikkan demand pada TPS dapat dilihat pada Tabel 4.

Pada kondisi saat ini 73 TPS yang ada di Kota Yogyakarta masih hanya dilayani oleh 1 TPA saja. Adanya usulan penambahan lokasi baru sebagai alternatif pilihan pembuangan sampah oleh keseluruhan TPS dengan mempertimbangkan jarak terdepat. Serta adanya

\begin{tabular}{|c|c|}
\hline Lokasi TPS & $\begin{array}{l}\text { Lokasi Pembuangan } \\
\text { Sampah Terbaik }\end{array}$ \\
\hline TPS Koramil Kraton & TPA Piyungan \\
\hline TPS Keben & TPA Piyungan \\
\hline TPS J1. Pramuka & TPA Piyungan \\
\hline TPS Tamansari & TPA Sidorejo \\
\hline TPS J1. Mungur Pengok & TPA Sidorejo \\
\hline TPS Jl. Mungur Kusbini & TPA Piyungan \\
\hline TPS Jl. Kusbini & TPA Piyungan \\
\hline TPS Embung Langensari & TPA Piyungan \\
\hline TPS J1.Balapan & TPA Piyungan \\
\hline TPS J1. Klitren & TPA Piyungan \\
\hline TPS Belakang Duta Foto & TPA Piyungan \\
\hline TPS Jl. Krasak Barat & TPA Piyungan \\
\hline TPS Jl. Ungaran 1, 2, 3 \& 4 & TPA Piyungan \\
\hline TPS Jl. Patimura $1, \ldots, 7$ & TPA Piyungan \\
\hline TPS Jl. Sabirin $1, \ldots, 6$ & TPA Sidorejo \\
\hline TPS Jl.Nyoman Oka 1 \& 2 & TPA Piyungan \\
\hline $\begin{array}{l}\text { TPS Komplek Balai Yasa 1,2, } \\
\& 3\end{array}$ & TPA Piyungan \\
\hline TPS Komplek Pamungkas & TPA Piyungan \\
\hline TPS Perikanan Sagan & TPA Piyungan \\
\hline TPS SMP 1 & TPA Piyungan \\
\hline TPS Telkom & TPA Piyungan \\
\hline TPS SMP 5 & TPA Piyungan \\
\hline TPA Barat Jembatan Layang & TPA Piyungan \\
\hline TPS Wisma Hartono & TPA Sidorejo \\
\hline TPS RS DKT & TPA Piyungan \\
\hline
\end{tabular}

kenaikan demand sebesar 55\% dapat mempengaruhi alokasi pengangkutan sampah pada TPS yang di angkut menuju TPA. Hal ini bertujuan untuk memaksimalkan kapasitas dari

Tabel 4. Analisis Sensitivitas dari kenaikkan demand $\left(d_{i}\right)$.

\begin{tabular}{|c|c|c|c|c|}
\hline \multirow{2}{*}{$\begin{array}{l}\text { Total } \\
\text { Demand } \\
\text { (di) }\end{array}$} & \multicolumn{2}{|c|}{$\begin{array}{c}\text { Jumlah } \\
\text { Alokasi TPS ke - }\end{array}$} & \multicolumn{2}{|c|}{$\begin{array}{c}\text { Jumlah } \\
\text { Tonase sampah }\end{array}$} \\
\hline & $\begin{array}{l}\text { Piyu } \\
\text { ngan }\end{array}$ & Sidorejo & $\begin{array}{l}\text { Piyunga } \\
\mathrm{n}\end{array}$ & $\begin{array}{l}\text { Sidorej } \\
\text { o }\end{array}$ \\
\hline $\begin{array}{l}112.67 \\
\text { (Existing) } \\
112.67\end{array}$ & 73 & 0 & 112.67 & 0 \\
\hline $\begin{array}{l}\text { (Lokasi } \\
\text { baru) } \\
174.64 \\
\text { (Naik 55\%) }\end{array}$ & 65 & 20 & 87.97 & 24.70 \\
\hline
\end{tabular}


masing-maisng TPA terhadap kenaikkan demand pada setiap TPS. Dapat dilihat pada Tabel 4.5 perubahan demand secara signifikan mempengaruhi alokasi pemilihan tempat pembuangan akhir sampah di Kota Yogyakarta.

\section{KESIMPULAN}

Berdasarkan pemodelan pemilihan lokasi pembuangan akhir sampah dengan penambahan lokasi pembuangan baru. Total jarak minimum yang digunakan untuk alokasi penentuan TPA untuk masing-masing TPS di Kota Yogyakarta adalah $1069.583 \mathrm{~km}$. Dengan alokasi seluruh TPS yang di angkut menuju masing-masing TPA dengan batasan kapasitas daya tampung TPA. Kenaikkan demand dapat mempengaruhi penentuan alokasi TPS yang akan di angkut oleh kendaraan menuju ke beberapa TPA.

Pada penelitian selanjutnya, pemodelan lokasi pemilihan tempat pembuangan sampah akhir ini dapat mempertimbangkan model penentuan letak fasilitas baru. Dan juga pemodelan alokasi ini dapat mempertimbangkan rute kendaraan yang mengangkut sampah dari TPS menuju TPA. Diharapkan penelitian selanjutnya dapat memperkaya keilmuan dalam pengembangan pemodelan pada penelitian ini.

\section{DAFTAR PUSTAKA}

Buhrkal, K., Larsen, A., \& Ropke, S. (2012). The Waste Collection Vehicle Routing Problem with Time Windows in a City Logistics Context. Procedia - Social and Behavioral Sciences, 39, 241-254. https://doi.org/10.1016/j.sbspro.2012.03. 105

Das, S., \& Bhattacharyya, B. K. (2015). Optimization of municipal solid waste collection and transportation routes. Waste Management, 43, 9-18. https://doi.org/10.1016/j.wasman.2015.0 6.033
Huang, S., \& Lin, P. (2015). Vehicle routing scheduling for municipal waste collection system under the "Keep Trash off the Ground" policy \$. Omega, 55, 24-37. https://doi.org/10.1016/j.omega.2015.02. 004

Islam, Md. Mohibul., Ghosh, Sajal., Rahman, M. M. (2015). Solving Capacitated Vehicle Routing Problem by Using Heuristic Approaches: A Case Study. In Global Engineering Science and Technology Conference.

Mulasari, Asti., Husodo, Adi Hereu., Muhadjir, N. (2016). A Situation Analysis Of Waste Problem In Yogyakarta Municipality Indonesia And The Policy Prevention. Jurnal Kesehatan Masyarakat, 11(2). https://doi.org/http://dx.doi.org/10.15294 / kemas.v11i1.3521

Ramdhani, M. N., Baihaqi, I., \& Siswanto, N. (2018). Optimization of municipal waste collection scheduling and routing using vehicle assignment problem (case study of Surabaya city waste collection). IOP Conference Series: Materials Science and Engineering, $337(1)$. https://doi.org/10.1088/1757899X/337/1/012013

Sarajevo. (2015). Waste Weight Determination. https://doi.org/ISSN 1840-488X

Sukirno, S. (1994). Pengantar Teori Ekonomi Makro. Penerbit Raja Grafindo, Jakarta.

Sukirno, S. (2006). Teori Pengantar Ekonomi Makro. Jakarta: PT Raja Grafindo Persada.

Usman, Y. V., Ismail, A. H., \& Hidayah, N. Y. (2013). Pengembangan Model Pemilihan Lokasi Pembuangan Akhir Sampah Perkotaan ( Studi Kasus: Kota Jakarta Timur ), (April), 45-52. 